\title{
معالجة فيروس كورونا بإندونيسيا في ضوء مقاصد الثرعة
}

\author{
ألف رفدا شاه \\ طالب مركز الشيخ زايد لتعليم اللغة العربية لغير الناطقين بها في الأزهر الشريف \\ Email: alifrifdansyah693@gmail.com
}

\begin{abstract}
مستخلص البحث
هذا البحث تحت موضوع "معالجة فيروس كورونا بإندونيسيا في ضوء مقاصد الشريعة". قد كتب لتصوير معالجة فيروس كورونا في إندونيسياعلى شكل عام و ضوء مقاصد الشريعة عنها. استطلع فروس الباحث الأدلة و المعلومات عنها بالقراءة و تتبع النسخة و قام على منهج الاستباط التحليلي في

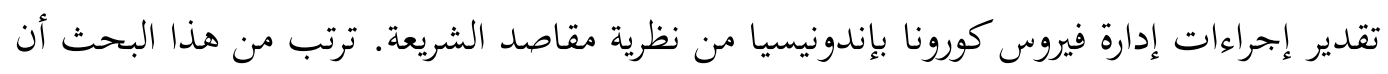
الإدارة قد جرت وفق الإرشادات من منظمة الصحة العالمية إلا في بعض القضايا التي مالت إلى لئ

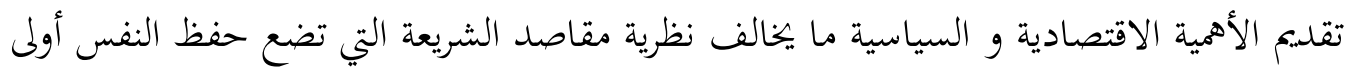

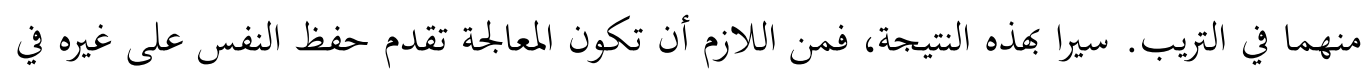

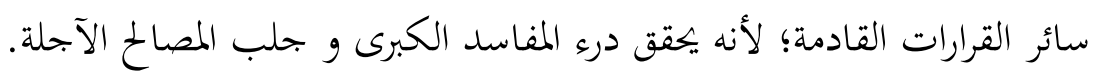
الكلمة الدليلية: مقاصد الشريعة، إدارة فيروس كورونا، حفظ النفس، الاقتصادية، السياسية
\end{abstract}

\begin{abstract}
This research is under the topic of "Managing Coronavirus in Indonesia perspective of Maqāsid Al-Sharia". It has been written to depict the management of Coronavirus in Indonesia generally and the view of the purposes of Sharia on it. The researcher explored the evidence and information about it by reading and tracing the transcript and based on the analytical deduction approach in estimating the procedures for managing Coronavirus in Indonesia from the theory of the purposes of Sharia. It follows from this research that the administration was conducted according to the guidelines from the World Health Organization, except in some cases that tended to present economic and political importance, contrary to the theory of the purposes of Sharia, which puts selfpreservation first in the order. Following this result, the administration must take precedence over others in all future decisions; because it is achieved to ward off major evils and bring future interests.
\end{abstract}

Keywords: Maqāsid Al-Sharia, management of Coronavirus, self-preservation, economic, politic 


\begin{abstract}
Abstrak
Penelitian ini mengambil topik "Penanganan wabah virus Corona di Indonesia dalam perspektif Maqasid al-Syariah" dengan tujuan menggambarkan pengelolaan penanganan virus Corona di Indonesia secara umum beserta pandangan Maqasid al-Syariah terhadapnya. Peneliti menggali bukti dan informasi dengan cara membaca dan menelusuri transkrip-transkip berdasarkan metode pendekatan deduksi analitis dalam meninjau prosedur penanganan wabah virus Corona di Indonesia dari sudut pandang Maqasid al-Syariah. Berdasarkan penelitian ini dapat disimpulkan bahwa penanganan wabah virus Corona dilakukan sesuai dengan pedoman dari World Health Organization, kecuali pada beberapa hal yang cenderung mengutamakan kepentingan ekonomi dan politik, dimana bertentangan dengan teori tujuan syariah yang mengedepankan pelestarian diri. Maka dari itu, penelitian ini berharap agar penanganan wabah virus Corona kedepannya mengedepankan pelestarian diri dalam setiap keputusan yang akan diambil; karena hal tersebut terbukti berhasil mencegah kerusakan yang besar dan membawa kemaslahatan bagi umum.
\end{abstract}

Kata Kunci: Maqāsid al-Syariah, Penanganan Virus Corona, pelestarian diri, ekonomi, politik

\title{
المقدمة أ. أ. خلفية البحث
}

$$
\begin{aligned}
& \text { ورود فيروس كورونا المستجد في العالم أصبح أزمة تستلزم بذل الجهاد العظيم و } \\
& \text { التضحية التي تطلب مالا حتى نفسا من كل بشر على وجه الأرض. و بعد ليال داجية، } \\
& \text { ظهرت الدول التي نجحت في إدارة تفشي الفيروس مع خلاف الدول الأخرى التي } \\
& \text { استخفتها في أول أمرها فتصير انتحارا عليهم في وقت لا يزيد عن شهر واحد. من أحسن } \\
& \text { الدول معالجةً على الجائحة: تايوان ( } 467 \text { حالة، } 7 \text { أموات) التي بححت بشكل مثير } \\
& \text { للإعجاب في احتواء فيروس كورونا دون إغلاقاقتصادها لأسابيع مثلما فعل العديد من } \\
& \text { الدول، إذ قامت بدلاً من ذلك بتثبيت قوانين حازمة دون تردد و مناظرة طويلة (دوكيس، } \\
& \text { 2020، الصفحات 181-182). } \\
& \text { ومن أسوأ الدول معالجة عليه المقتبس من موقع الومايات } \\
& \text { المتحدة (609،779،6 حالة، 793،198 موتا)التي تميل المعالجة كثيرا إلى أمور سياسية و } \\
& \text { اقتصادية دون الإغلاق الكبير ما يترتب من هذه الإدارة موت أكبر. وفقا على ذلك، فقد }
\end{aligned}
$$

Satgas ) تتشابه معالجة فيروس كورونا في إندونيسيا (262،000 حالة، 105،10 أموات

$$
\text { (Covid-19 كالدول التي دخلت في القائمة الدنيا للتنظيم حتى توفي من قبل الأطباء }
$$


127 مع أن نسبة طبيب واحد هي لم عالجة 2.500 مريض، بالإضافة إلى عدد المصابين و

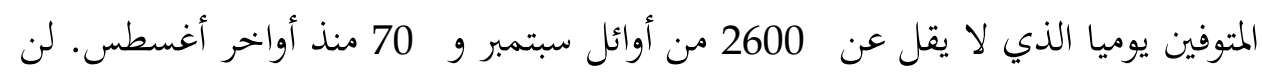
يلفت الانتباه إلا أن بعض القرارات التي أخذقا الحكومة و انتظام الرهط يصادمان الإدارة

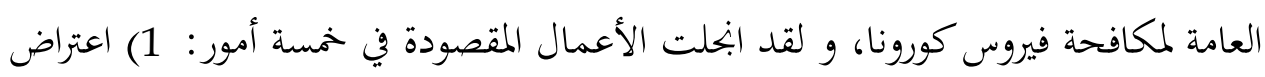
الوزراء الثلاثة على والي عاصمة جاكرتا في تشديد نظام تضييق النشاط الاجتماعي بأوسع نطاق ممكن(إدريس، 2020)، 2) تشكيل الفريق الخاص بوظيفة مكافحة كوفيد- 19 و إنعاش اقتصادية البلد الثابت في قرار رئيس الجمهورية ر. 9 س. 2020 عن ، 3) تطبيق التباعد الاجتماعي باصطلاح العيش في العادي الجلديد الذي لا يتصف بها حقيقة التباعد الاجتماعي الثابت في نظام الوزارة الصحية ر. 2020/382/01.07، 4) اتفاق الرئيس مع بحلس النواب على ثبوت عقد انتخاب المرشحين لرؤساء الدوائر (ريستياواتي، 2020، صفحة 86)، 5) تعدد عدم امتثال المجتمع البروتوكول الصحي العام، كمثل عقد البرنامج الموسيقي لأحد رجال بحلس النواب الفرعي(Kumparan، 2020).

بوجود هذه المظاهر المختلف فيها، نظر الباحث إلى أهمية تتبع معالجحة فيروس

كورونا بإندونيسيا من ضوء مقاصد الشريعة؛ ليتبين لدى المواطنين عامة أخذ أية عملية تساهم الدفع عن الفيروس على أساس القيم العامة يوافقها كلها جميع الناس دون اعتراض، و هي: حفظ النفس، حفظ العقل، حفظ الدين، حفظ النسل، و حفظ المال (الجمعة، صفحة 11)، حيث قد سارت الأحكام الإسلامية بل غيرها بهذه النواة ما قد حصل منها رد الشبهات الماردة.

انطلاقا مما قد سبق، رأى الباحث أن النظر من مقاصد الشريعة في معالجة فيروس

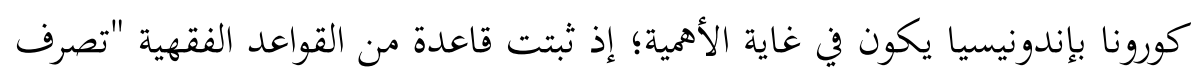
الإمام على الرعية منوط بالمصلحة" (الزحيلي، 2006، صفحة 493)، و بهذه قاس الباحث

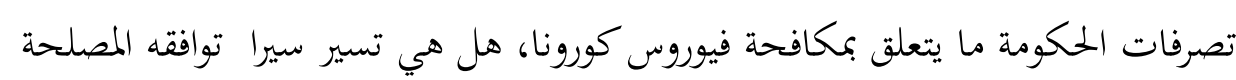
عند مقاصد الشريعة أو العكس.

ب. حدود البحث

مؤسسا على واسع نطاق البحث، قام الباحث بتحديد القضايا ؛ ليكون البحث

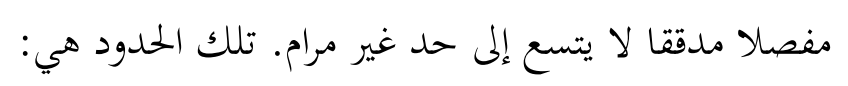


1. معالجة فيروس كورونا في إندونيسيا إجمالا و خاصة في الأمور الخمسة المذكورة يدخل فيها أوجه الاعتراض، فيخرج منها كل ما قد صلح جريه عند البحتمع. 2. معالجة فيروس كورونا بإندونيسيا في ضوء مقاصد الشريعة عند أهل السنة و الجماعة بنقطة التركيز إلى ترتيب الضروريات الخمس في الزمن المعاصر، فيخرج منها مقاصد الشريعة عند الفرق الضالة .

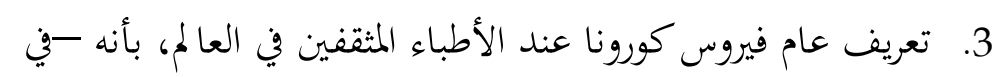
الاقتصار - مسبِب مرض معد وبائي، فيخرج منه تعريفات غير مصدرة على تلى التتبع.

\section{فيروس كورونا و نشأته في إندونيسيا}

\section{أ. تعريفه و كيفية انتشاره}

قد يتشابه بين الناس مصطلحات تتعلق بكورونا لتعددها في الأخبار و

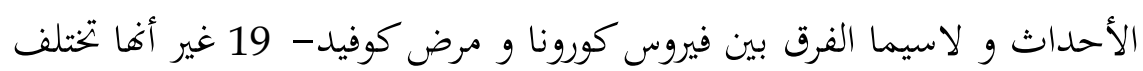
واقعيا إن نظرت من جهة الفترة.اتفق الأطباء في منظمة الصحة العالمية بأن

$$
\text { فيروسات كورونا هي: }
$$

"سلالة واسعة من الفيروسات التي تسبب لدى البشر أمراضا تنفسية

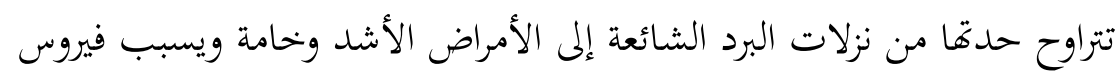
كورونا المركتشف مؤخراً مرض كوفيد-19". WHO)، 2020). من أوائل أمره، قد هجم الفيروس نواحي البشر المهمة و أثر تأثيرا مباشرا

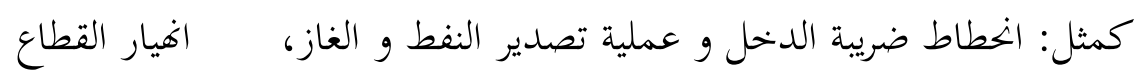
السياحي(أديتيا، إيرلينا، و مودا، 2020، الصفحات 213-214)، تداعي الناتج المحلي الإجمالي، انحسار النشاط الاقتصادي (وريانداني، 2020، صفحة 20)، و ما لفت انتباه الناس: منع دفن المتوفى المصاب بالفيروس في الدوائر العديدة. (داعي، 2020، صفحة 68). كما أن كل ذلك وظيفة لدى كل شخص لأن يتحد في الأخوة البشرية للحلول على هذه الجحائحة دون نظر إلى الفروق الطبيعية.

تحقق انتقال الفيروس عبر وسيلتين: القطيرات من إفراز المصاب إلى

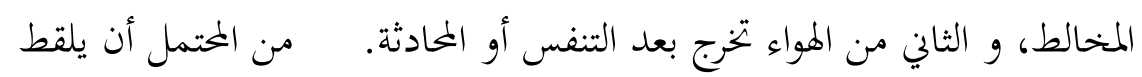




$$
\begin{aligned}
& \text { الأشخاص عدوى كوفيد- } 19 \text { من أشخاص آخرين مصابين بالفيروس، حيث } \\
& \text { ينتشر المرض بشكل أساسي من شخص إلى شخص عن طريق القُطيرات الصغيرة } \\
& \text { التي يفرزها الشخص المصاب بكوفيد- } 19 \text { من أنفه أو فمه عندما يسعل أو لئن } \\
& \text { يعطس أو يتكلم، كما أن فيروس كورونا يحتمل أن ينتشر عبر المواء. (بي شين و } \\
& \text { اخرون، 2020، صفحة 1670). } \\
& \text { ب. نشأة فيروس كورونا في أول أمره }
\end{aligned}
$$

تزعزع العالم بحضور مرض معد لم يعرف سببه حيث كان فيه أنواع من الاتمامات بين الدول الكبرى الثلاث على من هو سيكون مسؤولا لهذه المصيبة. أصابع الاتحام تتجه نحو الصين أكثر بناء على أن هذا الفيروس اكتشف في مدينة ووهان، إحدى مدنه. قبيل أن يصبح مرضا مرهبا لدى البشر، كان مستجدا لا يعرفه أي الخبراء في العالم، و قد ظنوا

$$
\text { أنه نوع من التهاب رئوي فيروسي. }
$$

بدءا من 31 ديسمبر 2019، اطلع المكتب القطري للمنظمة في جمهورية الصين

الشعبية على بيان إعلامي للجنة الصحة البلدية في ووهان نُشر على موقعها الإلكتروني

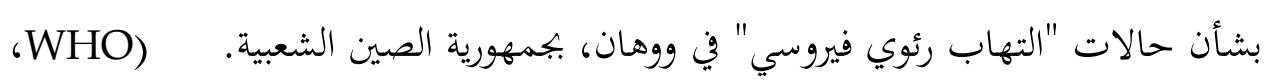

بعد مضي أيام للبحث ببذل جهد كبير، في 9 من يناير 2020، أفادت المنظمة

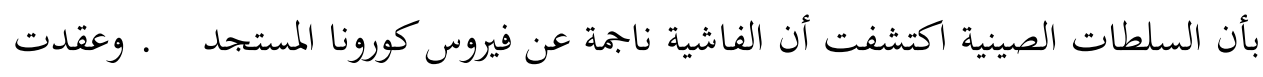
المنظمة أول مؤتمر من المؤتمرات العديدة التي عقدها عن بعد مع شبكات الخبراء العالمية، بدءاً من الشبكة السريرية، ثم نشرت الوثائق الإرشادية، تغطي مواضيع تتعلق بإدارة فاشيات الأمراض المستجدة في 10-12 يناير 2020.WHO)، 2020).

هذه الدوافع لم تنجح أي بجاح لسرعة انتشاره في القارات مؤسسا على إبلاغ وزارة الصحة في تايلند 13 يناير 2020 و في فرنسا 24 يناير 2020 عن حالات إصابة بفيروس كورونا، كما تستمر على زيادة الحالات حتى 965،429،32 بالإضافة إلى عدد المتوفين المصابين الذي بلغ (covid19.who.int).823،985. 


\section{معالجة فيروس كورونا بإندونيسيا في ضوء مقاصد الشريعة \\ أ. مقاصد الشريعة و أقسامها}

وفقا بقول الإمام الشاطبي، إن المقاصد روح الأعمال؛ لثبوت العمل المنبني عليه,

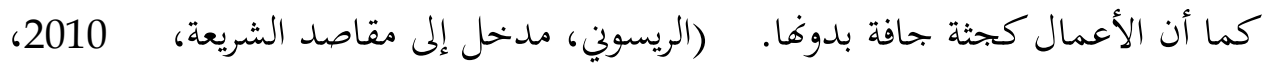

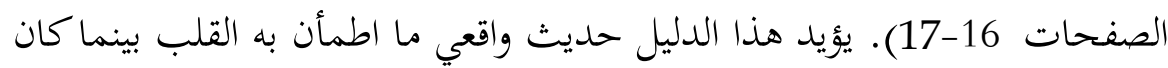

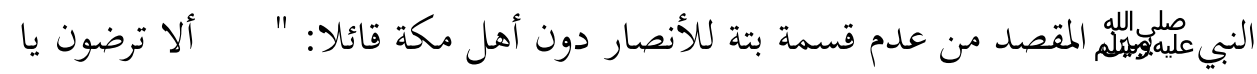

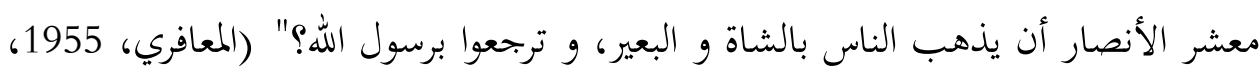

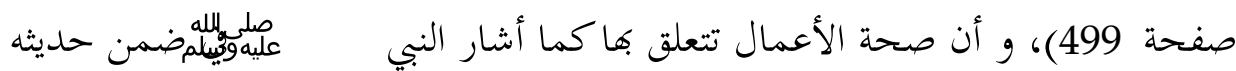

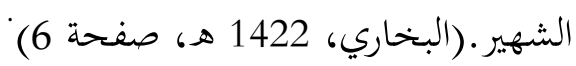

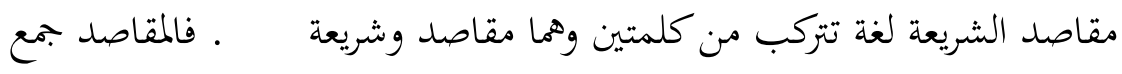
مقصد وهو يشتق من القصد بمعنى استقامة الطريق (منظور، 1990، صفحة 353) لقوله

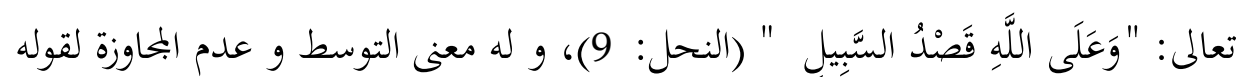

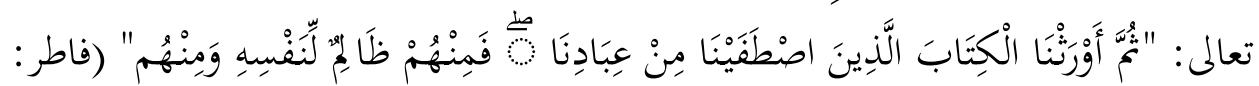

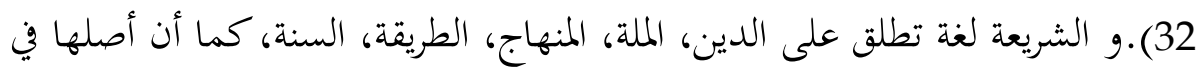

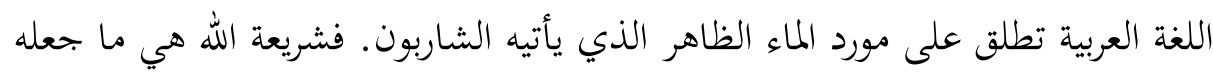

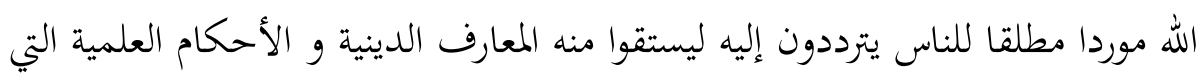

$$
\text { كلفهم بها الله عز و جل. (الجمعة، صفحة 3). }
$$

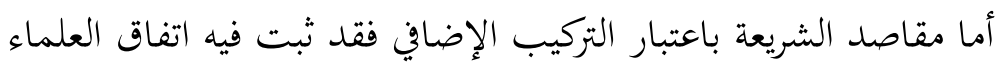

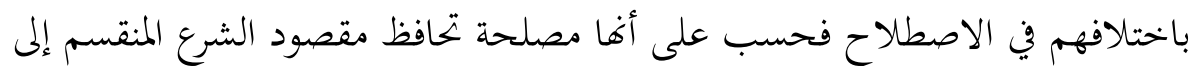

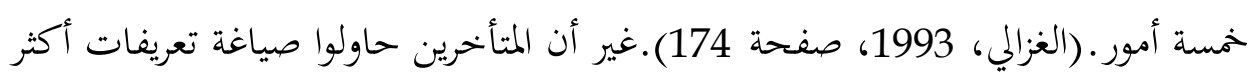

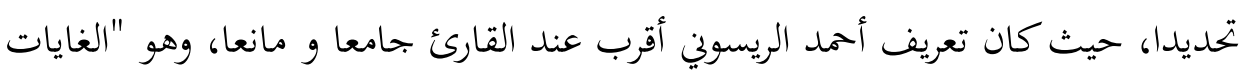

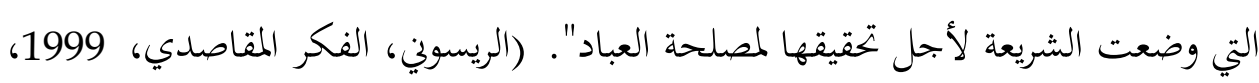

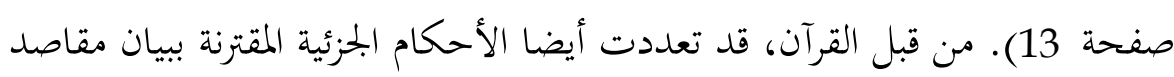

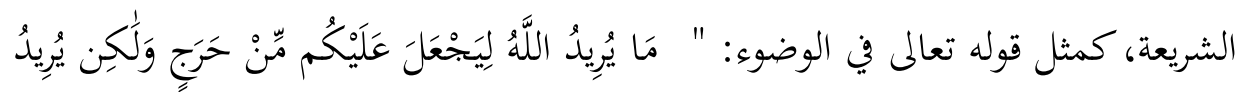

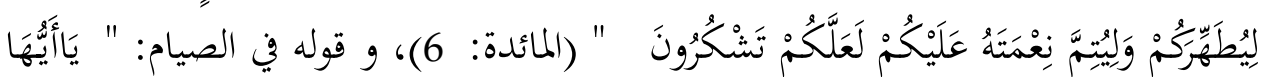

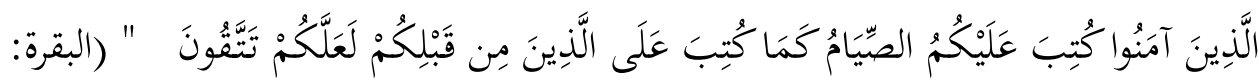


183)، و هكذا بين القرآن أحكامه ليكون العمل بها أنشط لدى العبد حيث كانت كل الايات المذكورة يدركها العقل على شمول المصلحة للبشر و حفظ الشرع.

$$
\text { تنقسم مقاصد الشريعة من حيث أهميتها إلى ثلاثى أقسام: }
$$

$$
1
$$

هي ما لا بد منها في قيام مصالح الدين والدنيا، بحيث إذا فقدت

لم بحر مصالح الدنيا على استقامة. و هذه الضروريات خمس و هي: الدين

و النفس و العقل و النسل و المال، بينما كان الترتيب أقوى مراتب المصالح،

من أمثلتها وجوب تحصيل المال بطريقة لا بحاوز حقوق الغير. (وهبة، 1986،

صفحة 1021).

$$
2
$$

هي ما كان مُفْتَقَراً إليها من حيث التوسعة ورفع الضيق المؤدي إلى

الحرج والمشقة اللاحقة بفوت المطلوب، ولكنه لا يبلغ مبلغ الفساد العادي

المتوقع في المصالح العامة، و رتبتها بعد الضروريات، من أمثلتها إباحة الفطر

في رمضان للمريض و المسافر. (وهبة، 1986، الصفحات 1022-123).

$$
3 \text { - المكملات أو التحسينيات }
$$

وهي المصالح التي تقتضيها المروءة، و يقصد بها الأخد بمحاسن

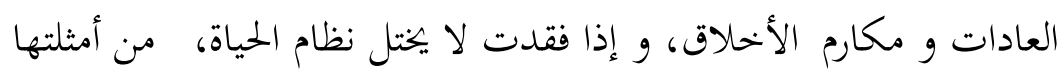

$$
\text { ستر العورة في الصلاة.(وهبة، 1986، صفحة 1023). }
$$

من البيان السابق، تبين أن الإسلام دين العقل و العلم بتنظيمه شئون الناس غير

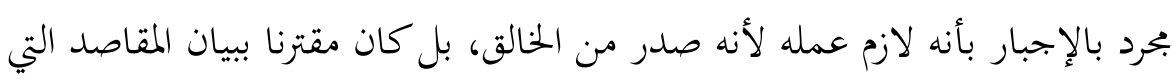

$$
\text { يقبلها العقل من غير شك. }
$$

\section{ب. الاختلاف بين العلماء في ترتيب الضروريات الخمس}

تفرق العلماء المتقدمون في ترتيب الضروريات الخمس إلى قسمين: قسم وضع

الدين في الأول و قسم وضع الدين في الآخر . القسم الأول رتبها بهذا الترتيب: حفظ الدين، حفظ النفس، حفظ العقل، حفظ النسل، و حفظ المال بناء على تفسيرهم مفهوم الدين بكماله أو الدين بمعنى العقيدة كالغزالي. خحلافا على ذلك، فقد أشار القسم الثاني 
إلى وضع الدين في الآخِر لأن حقوق الآدمي مقدمة على الدين، و أن المراد بالدين العبادة

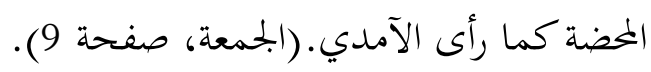

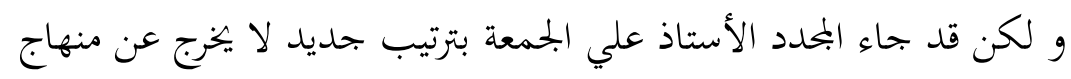
السلف، و ذلك الترتيب: حفظ النفس، حفظ العقل، حفظ الدين، حفظ النسل، و

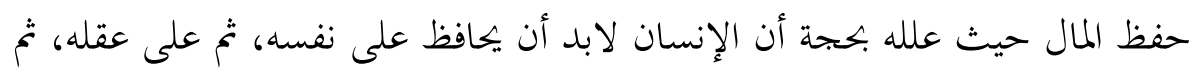

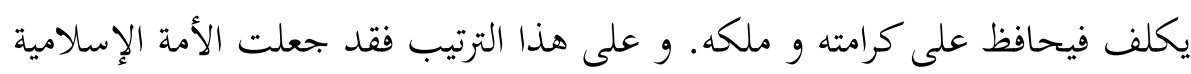
نظاما يصلح لغير المسلمين؛ لأنه متفق عليه لدى البشر، كما أن اليوم الأهمية البشرية

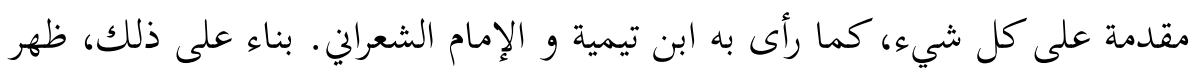

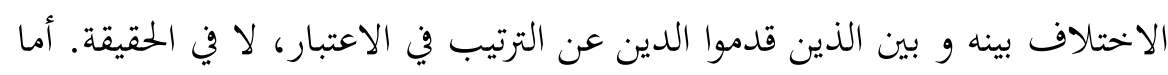

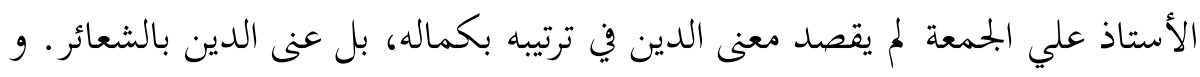

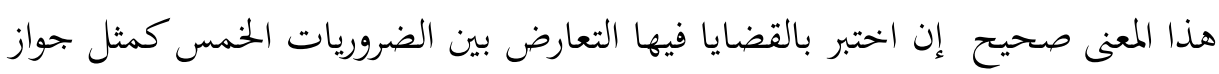

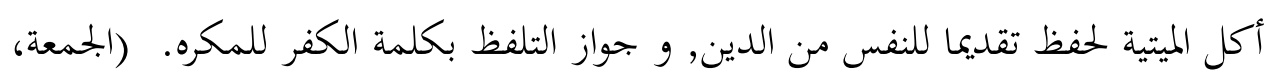

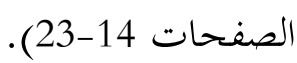

من هذا البيان، لقد اتضح أن العلماء اتفقوا على ترتيب أقسام مقاصد الشريعة

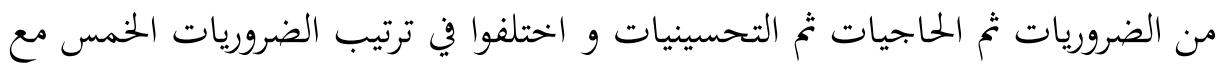

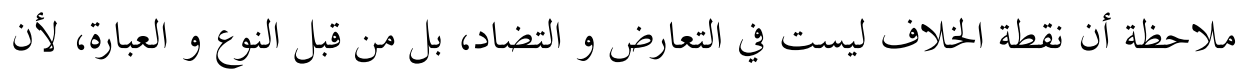

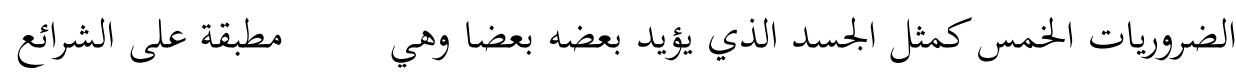
نفسها. (الجمعة، صفحة 23).

\section{ت. أهمية تطبيق مقاصد الثريعة في الحياة البشرية}

سيتضح بيان أهمية تطبيق مقاصد الشريعة في الحياة البشرية بإظهار فوائدها

المنتاجة بعد تفعيلها في الأحكام الشرعية الملخصة في الأمور التالية:

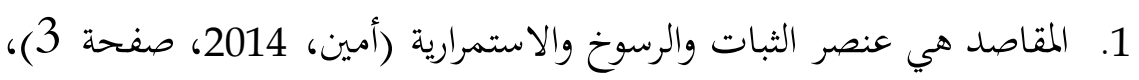

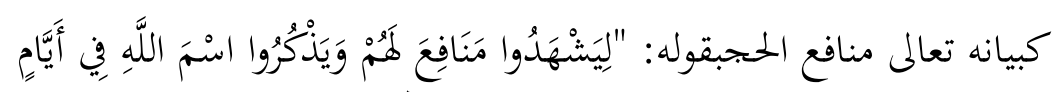

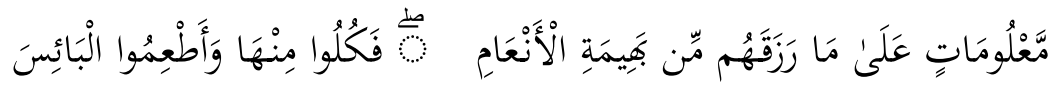

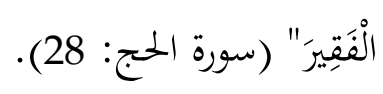


2. المقاصد تزيل الكلل وتسدد العمل (أمين، 2014، صفحة 3)، كمثل إجابة رسول الله عن دخول المقتول النارحين سأله صحابي: " إِنَّهُ كَانَ حَرِيصًا عَلَى لَّلى

$$
\text { قَتْلِ صَاحِبِهِ".(البخاري، } 1422 \text { هـ، صفحة 15). }
$$

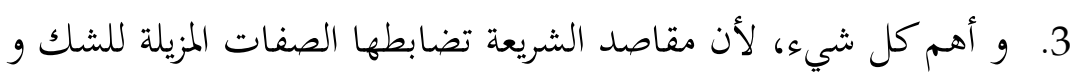

المقبولة عند العقول السليمة، بمعنى أهما تتحقق بضوابط جلية صريحة ضخمة. و تلك الضوابط هي: 1) الثبوت، كمثل حفظ المال كغاية من حرمة السرقة فهو ثابت بالنص و اتفاق أهل الأرض. 2) الظهور، كمثل حفظ المال كغاية في حرمة السرقة فهو ظاهر بالتحقيق في المنافع و يزيل الخفاء في عدمها. 3 (3) الانضباط، كمثل انضباط شرب الخمر بجرعة منها؛ لاختلاف دبيب السكر

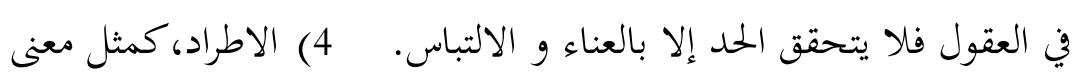

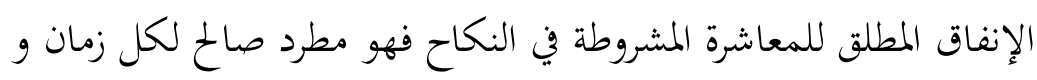
مكان و لا يدخل في الإنفاق معنى اخر يخالف المعنى الأول. (عمر، 2009،

$$
\text { الصفحات 278-292). }
$$

في ضوء ما سبق، تبلور أن مقاصد الشريعة نظرا من ضاحية النظرية و الواقعية في

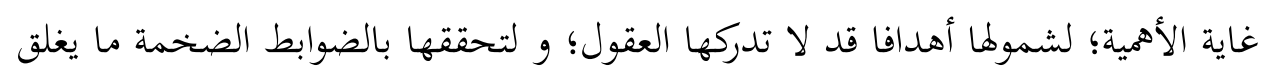

$$
\text { باب اختلال الشك و الوهم. }
$$

\section{ث. معالجة فيروس كورونا بإندونيسيا}

وصل فيروس كورونا في إندونيسيا بعد شهر و زائد من أول أمره، و ذلك عبر

يباني مصاب بالفيروس خالطته امرأة إندونيسية كانت صاحبته ثم خالطتها أمها أيضا، ثم أصبحتا متهمتين بالفيروس على أساس البيانات من المختبر بعد سبق اكتشاف الياباني بأنه مصاب في ماليزيا، كما أن رئيس الجمهورية أعلم بوجود أول حالة في (المتقين و أنصار، 2020، صفحة 162).

لا شيء بعد إعلام الرئيس إلا دوام تزايد عدد المصابين بالفيروس حتى قد أُجبرت أُ أحبرت

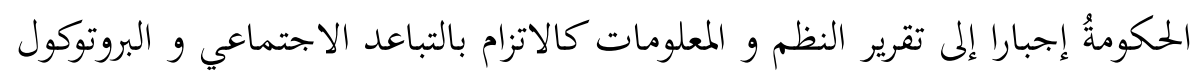
الصحي، و تشكيل اللجنة الخاصة في متابعة الفيروس حيث أخرجت قرارا بتضييق النشاط 
الاجتماعي في 30 مارس 2020 نظرا إلى الانتشار الحاد في 29 إقليما بالإضافة إلى بلوغ عدد المصابين انذاك 1414 حالة و 122 موتا. (Satgas Covid-19).

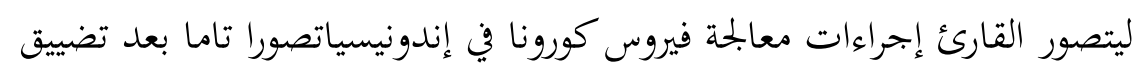

$$
\text { النشاط الاجتماعي، قسمها الباحث إلى ثلاث فترات: }
$$

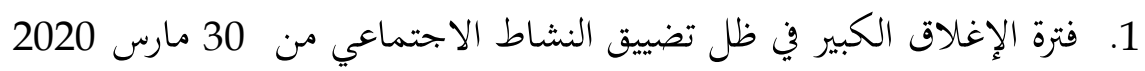

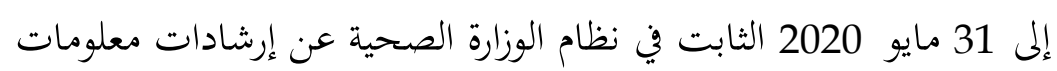
تتعلق بتضييق النشاط الاجتماعي الرقم 09 سنة 2020 و نظام حكومة

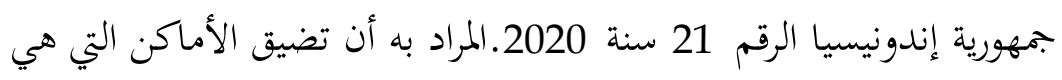
نقطة ازدهام الناس كمثل: المدارس و الدواوين، و يستثنى منها: الأقسام الاستراتيجية في الاقتصادية، و الخدمة العامة.

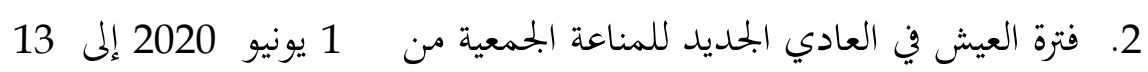

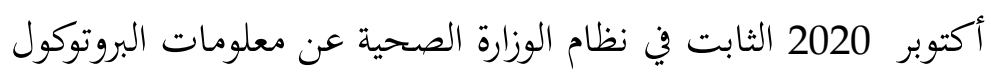

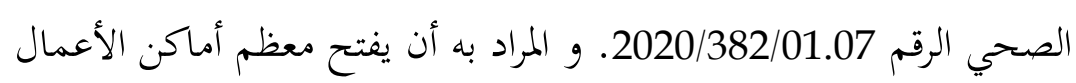
بغاية إنعاش الاقتصادية.

3. فترة تفعيل تضييق النشاط الاجتماعي للمرة الثانية في عاصمة جاكرتا من 14

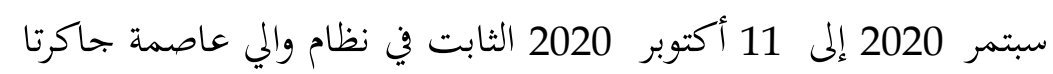

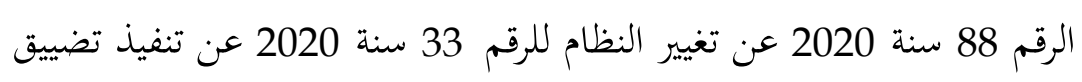
النشاط الاجتماعي الثاني. و المراد به التضييق كما في الفترة الأولى بتغيرات قليلة في الأقسام المسموح عملها.

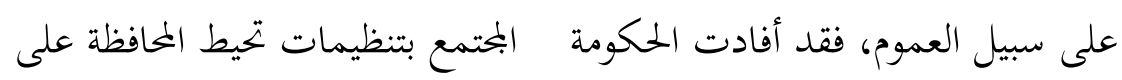

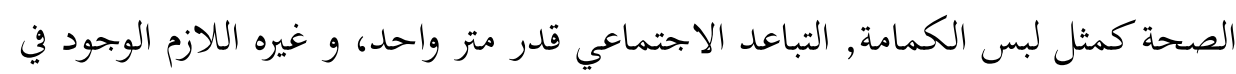

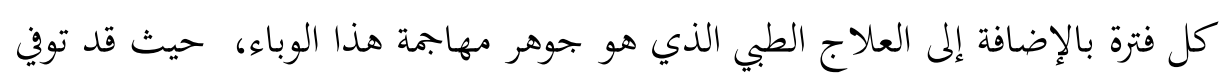

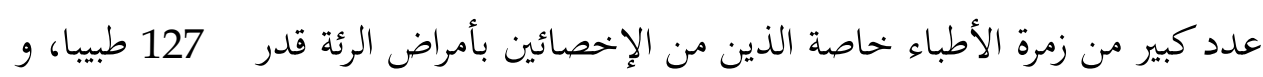

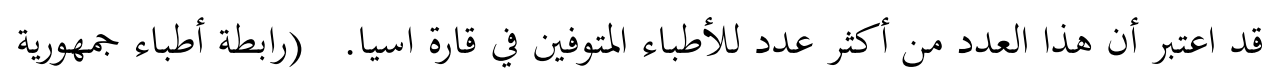
إندونيسيا، 2020، صفحة 16). 
مما يدعو للاستغراب، أن الخطورة الحادة في هذة الوحلة لم تدع بعض الفرق

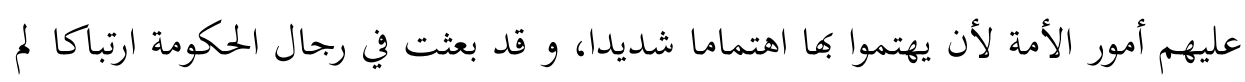
يعط الخيرة إلا الشرين: انقضاء الاقتصادية مع التركيز في العلاج الصحي، أو العكس.

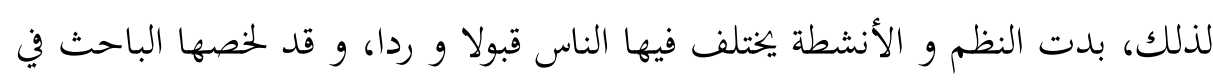

$$
\text { الأمور الخمسة مع أوجه الاعتراض كما يلي: }
$$

1 - اعتراض الوزراء الثلاثة على والي عاصمة جاكرتا في تشديد نظام التباعد إصد

الاجتماعي تارة أخرى؛ لإنعاش الاقتصادية التي تنحط في الفصلين الأولين

2020، بخلاف رأي والي العاصمة على القائل العكس. (نظام والي عاصمة

$$
\text { جاكرتا الرقم } 88 \text { سنة 2020). }
$$

2 - تشكيل رئيس الجمهورية الفريق الخاص بوظيفةين: مكافحة كوفيد- 19 و

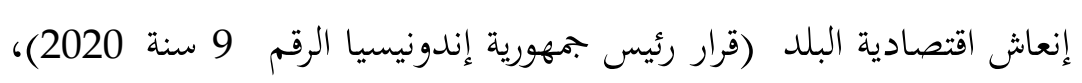
إلا أن العبء ليس كمثقال ذرة مؤسسا على تدهور الأحوال يوميا.

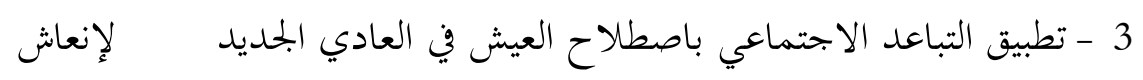

اقتصادية البلد أيضا (نظام الوزارة الصحية عن معلومات البروتوكول الصحي لاصي

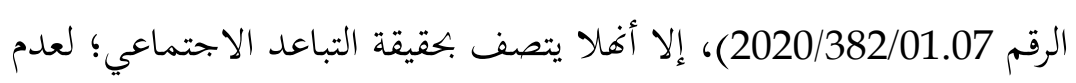

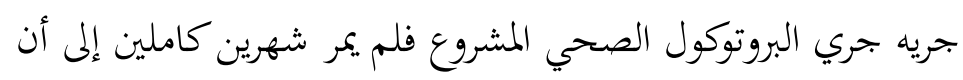
اكتشف أكثر من ألفي مصاب في واحد (Satgas Covid-19)، و انحسار النشاط الاقتصادي في الفصل الثاني إلى -5,32 ، و الفصل الثالث إلى -

$$
\text { 3,49\%.(المكتب المركزي للإحصاء الرقم 85، 2020). }
$$

4 - اتفاق الرئيس مع بحلس النواب على ثبوت عقد انتخاب المرشحين لرؤساء

الدوائر في 9 من ديسمبر 2020(ريستياواتي، 2020، صفحة 86)نظرا إلى ني

عدم قطعية ثبوت هاية الجائحة، الحفاظ على جمهورية الدولة المتمسكة بالدستور العام، و ضمان الحكومة على مسير الانتخاب مراعيا بالبروتوكول الصحي، بخلاف تحقق الواقع بأن 243 مرشحا قد جاوزوا البروتوكول

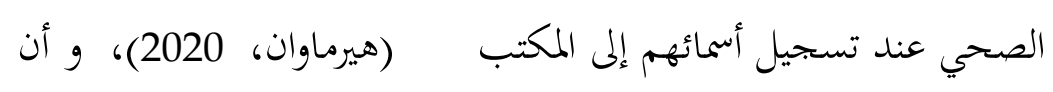
المصابين بالفيروس منهم 60 شخصا (cnnindonesia، 2020). 


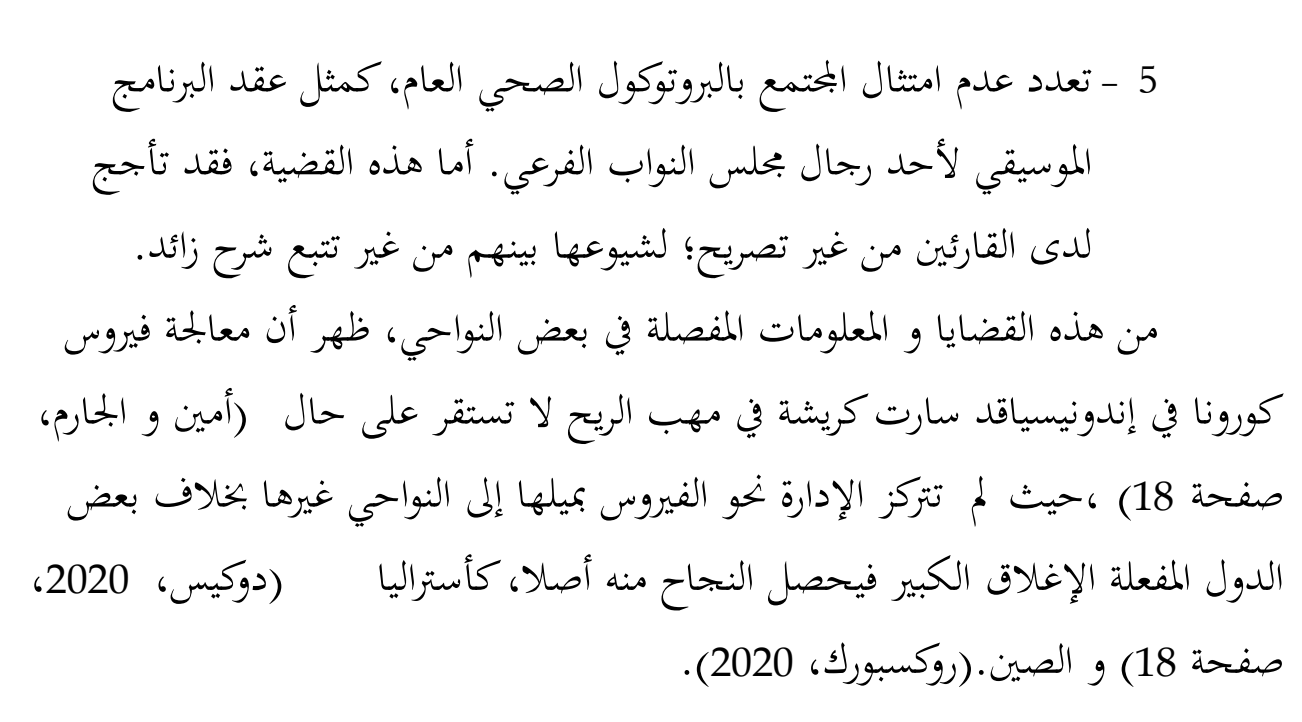

\section{ج. معالجة فيروس كورونا بإندونيسيا في ضوء مقاصد الثريعة}

لخص الباحث القضايا الخمس المذكورة قبل في نطاق واحد و هو قضية تقديم فيكي

الحفظ على غير النفس لارتباط كل قضية بالاخرى فيه و لشمولها الأهمية الاقتصادية و

غيرها أكثر بدليل: 1) اقتراح ثلاثة الوزراءإنعاش النشاط الاقتصادي بتأجيل تفعيل تضييق النشاط الاجتماعي مرة ثانية، 2) تطبيق نظام العيش في العادي الجديد, 3) انحسار الناتج

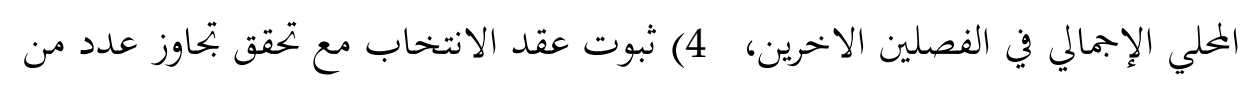
المرشحين البروتوكول الصحي.

و لسعة مباحث المقاصد، استبط الباحث منها لهذا الإطار أربعة مناهج بالترتيب

ليتتبع عليها و يقيس بها معالجة فيروس كورونا في إندونيسياحيث ترتكز نقطة البحث في الأمور الخمسة الملخصة في قضية تقديم الحفظ على غير النفس. تلك المناهج هي : 1

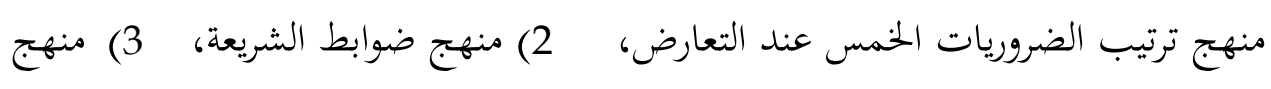
المصلحة بذاتما، 4) و منهج الوسائل و الغايات.

في نظرية ترتيب الضروريات الخمس عند التعارض بين حفظ النفس و المال، روعي فيها المفسدة العظمى بارتكاب الصغرى - كما رتب الدكتور وهبة الزحيلي (وهبة،

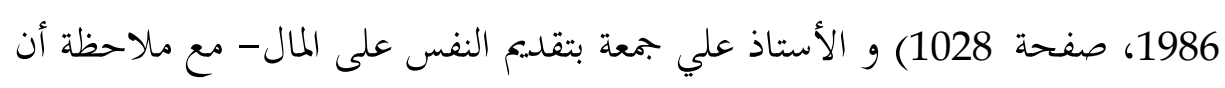
المفسدة الكبرى بالطبع تتولد من تأخير حفظ النفس، و أن مقابل النفس هو النفس و لا لا

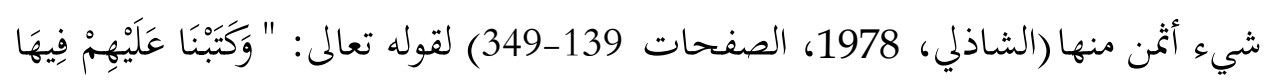
أَنَّ النَّفََْ بِالَّفْسِ " (المائدة: 45)، بالإضافة إلى البراهين المؤكدة لها كدوام تزايد عدد 
المصابين و المتوفين و انحسار النشاط الاقتصادي، و كما تحققت المصلحة من تقلديم حفظ النفس في الصين بإقامة الإغلاق الكبير أياما ما ترتب منها عدم بلوغ عدد المصابين مائة

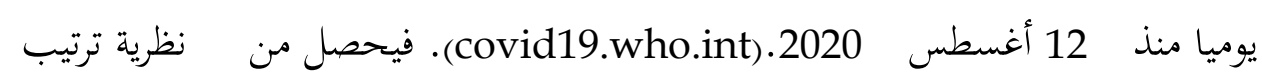

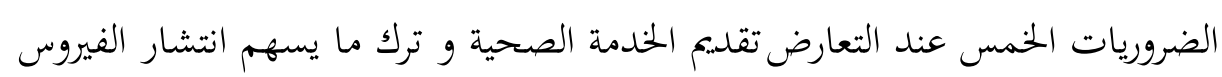
كالأعمال في الدواوين و لو كان فيهما ضيق و مشقة. أما التعارض بين حفظ النفس و انتخاب مرشحي رؤساء الدوائر فإنه لم يدخل في الضروريات بل في الحاجيات حيث كان ضياعه أو تأجيله لم يضر حفظ النفس لوجود القانون في تنظيم الدائرة من غير وال (أي له بديل من الحكومة) و وجوده محققا على لى جلب المفسدة في إسهام انتشار الفيروس بعدم الانتظام بالبروتوكول الصحي. (جريدة جاوا فوس، 28 سبتمبر 2020، صفحة 1).

و من ضوء ضوابط المصلحة (التي يشترط فيها الثبوت، الظهور، الانضباط، و

الاطراد) فلم يسلك مقصد إنعاث الاقتصادية و حفظ الدستور العام عند الجائحة الثبوت لغلبة الشك و عدم جزم التحقق فيهما بناء على الانحسار في الفصلين و تعدد المحاوزة

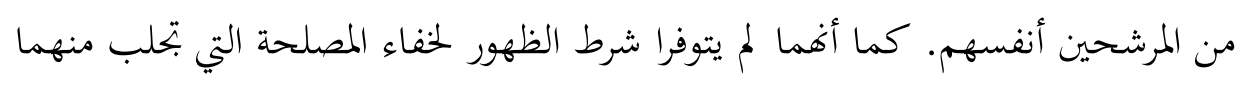
و وقوع اختلاف أنظار البمتهدين حيث يميل منهم إلى تقديم المصلحة المباشرة بالصحة. و و

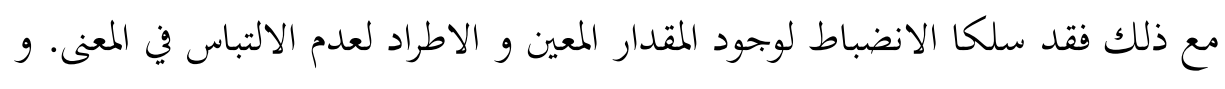
حصل من نظرية ضوابط المصلحة عدم تحقق المصلحة في معالجحة فيروس كورونا بطرق منها تفعيل النشاط الاقتصادي بشكل كبير و عقد الانتخاب العام لرؤساء الدوائر عند

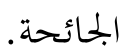
ثم من ناحية المصلحة بذاتا، فقد أشار الأستاذ أحمد الريسوني إلى معالمها حيث يجب أن تنظر و توازن المصلحة قبل تأكدها وعملها من أربعة أمور: من مآلات

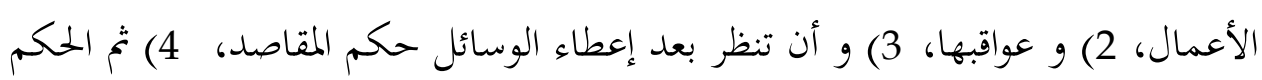
على الوسائل حكم المقاصد؛ و ذلك لأن الناس عادة ينظرون إلى ما فيه مصلحة قريبة عاجلة على أنه مصلحة لهم، ولو كان وسيلة إلى مفسدة آجلة خطيرة الشأن، و ينظرون إلى ما فيه كلفة أو ضرر عاجل على أنه مفسدة لهم، و لو كان وسيلة إلى مصلحة آجلة

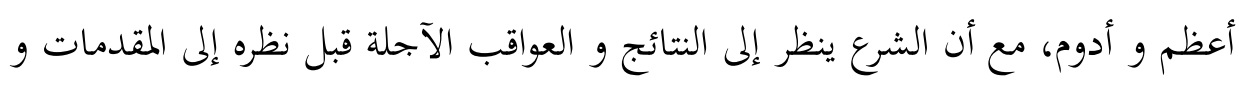


النتائج العاجلة (الريسوني، مدخل إلى مقاصد الشريعة، 2010، الصفحات 60-61)؛ و و

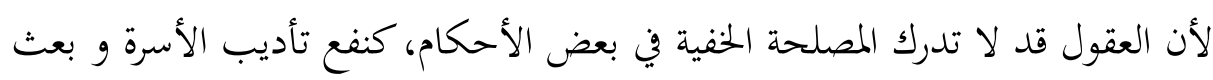
شعور الأخوة بينهم في قضية وجوب دفع الدية عليهم إذا عجز القاتل (عاشور، 2011، صفحة 280)، و أيضا في منافع مشروعية الصوم من الصحةو العلم بشعور الفقير.(الجوزي، 1986، صفحة 74).

و لما قدمت المعالجة بالفيروس الشؤون الاقتصادية و السياسية بينما يجيط بالناس تهديد الموت من الفيروس، فعندئذ قد نظرت الإدارة إلى ما فيه مصلحة قريبة عاجلة مع الغفلة عن مصلحة آجلة أعظم و أدوم، و هي حفظ المجتمع عن الموت بالفيروس. فيحصل من نظرية المصلحة بذاتما عدم تشكل المصلحة تشكلا تاما في دفع الفيروس بتفعيل النشاط الاقتصادي بشكل كبير و في عقد الانتخاب العام لرؤساء الدوائر عند الجائحة.

$$
\text { و كما قال العز بن عبد السلام: }
$$

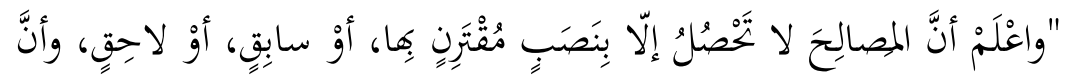

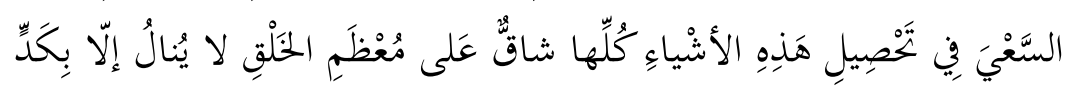

$$
\text { وتَعَبٍ". (السلام، 1991، صفحة }
$$

بين سلطان العلماء واضحا أن المحاولة لإيجاد المصلحة فيها مشقة و كد، و ولكن كان وراءها لذة و نعمة للناس عامة. ففي تقديم حفظ النفس أنواع من المشقات و أقدار من الجهود و الكد، غير أن آجل كل ذلك مصلحة متحققة.

و من ناحية الوسائل و الغايات في إيجاد المصلحة(عودة، 2011، الصفحات 77-

83)، فقد أصبح رفع حرج فيروس كورونا و دفع الضرر عنه في بحال الغايات الثابتة، بخلاف تفعيل النشاط الاقتصادي الذي هو بحرد الوسيلة من وسائل إدارة الفيروس. فإن فئ

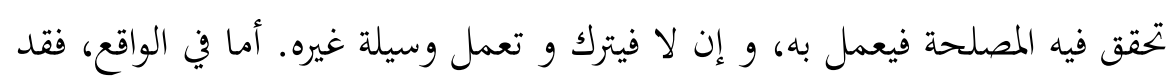
ازدادت الإدارة بعدا عن غاية التخلص من الفيروس. و في قرار الحكومة بعقد الانتخاب عند الجائحة لحفظ الدستور العام، فإن الانتخاب أيضا بحرد الوسيلة من وسائل حفظ

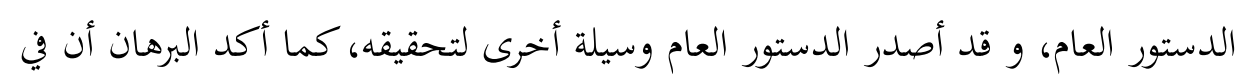
الانتخاب إسهاما في انتشار الفيروس. 
أما تقديم التحسينيات على الضروريات وهي حفظ النفس كعقد برنامج الموسيقى، فلا يحتاج إلى الحجة عليه من نواحي مقاصد الشريعة لإجماع الناس على رفضه، إلا أن التطبيق في إقامة التعزير للمجاوزين لم يكن حازما مرتبطا بين كل جهة، إما من جهة المجتمع و إما من جهة الحكومة. هذه التحليلات المذكورة أثنتها البحثان على الأقل، حيث ينتج من الأول -الذي بحث عن تضييق النشاط الاجتماعي في ضوء مقاصد الشريعة- أنه قد وافقته المقاصد؛ لأن الحكومة سدت ذرائع المحاوزات من ضمن المحتمع أكثر مستويا بتعديل النشاط الاقتصادي على قدر الحاجة. (المتقين و أنصار، 2020، صفحة 160). أما البحث الثاني -الذي بحث عن سياسة الحكومة في فترة العيش في العادي الجحيد- فقد أشار إلى وجود

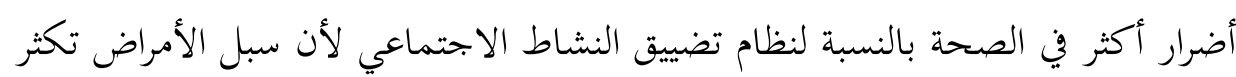
مفتوحةً.(بالله، 2020، صفحة 140).

لذلك، رأى الباحث أن معالجة فيروس كورونا بإندونيسيا إن تزل بتحري جريا يمينا

و شمالا حيث تقدم حفظ المال و السياسة،فسوف يترتب من ذلك مفاسد كبرى ما لا يدركها العقل، كما كان بعض الناس في أوائل سنة 2020 الذين لا يعتنون بخطورة هذا الفيروس، فأصبحوا واعين بها بعد أن أظهر الفيروس صياحه و نابه أمام بحتمع العالم كله.

الخاتمة

\section{أ. أ. الاستنباط}

بعد إيضاح البيان في الأبواب السابقة و تخطيط الصورة العامة ، استنبط الباحث هذه القضية إلى نقطتين: - مإن 1. إجراءات معالجة فيروس كورونا في إندونيسياتجري جريا موافقا النظم العامة في

$$
\text { ناحية الخدمة الصحية لكن معترضا في خمسة أمور. }
$$

2. معالجة فيروس كورونا في إندونيسيا وافقته مقاصد الشريعة؛ لجريها كما أشار

أطباء العالم إلا في خمسة أمور تتلخص في قضية تقديم الأهمية الاقتصادية و السياسية. فقد رأى الباحث أن تقديم حفظ النفس في ضوء مقاصد الشريعة أهم منهما نظرا من اعتبار جلب المصلحة و درء المفسدة في ترتيب الضروريات الخمس و ضوابط المصلحة و حقيقة المصلحة بذاتا. 
يتسم البحث عن معالجة فيروس كورونا في إندونيسيا بالمرونة حيث تدخل فيه

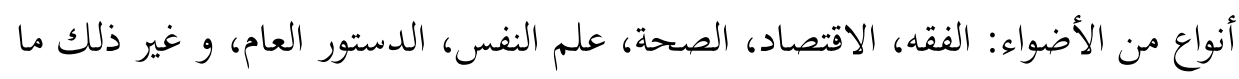

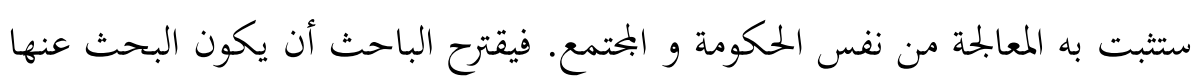

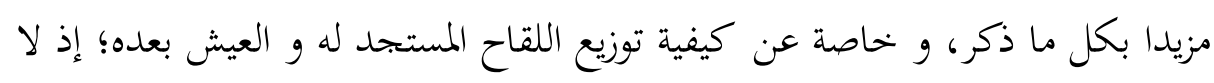
يستحيل بقاء الأضرار، و لأن الافتراض سيصبح تخطيطا أساسيا في تغليق الإمكانات

$$
\text { السيئة. }
$$

مصادر البحث

أ. الكتب

القرآن الكريم

ابن أيوب الحميري المعافري، عبد الملك بن هشام، السيرة النبوية لابن هشام، (مصر:

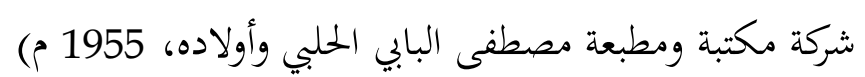

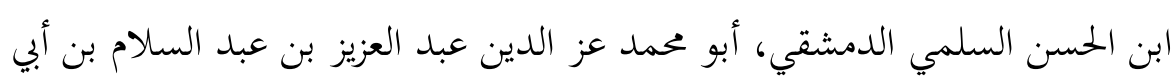

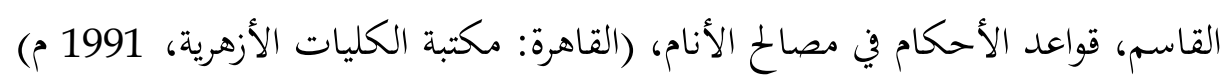

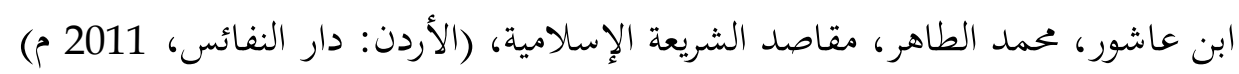

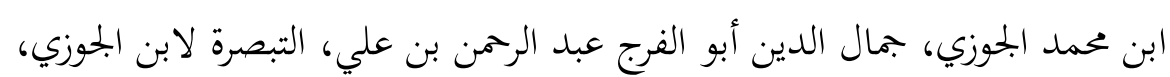

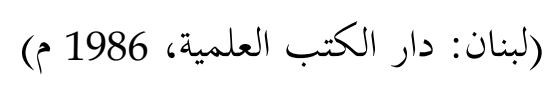

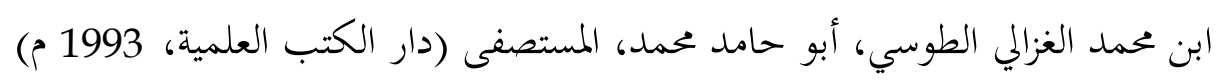

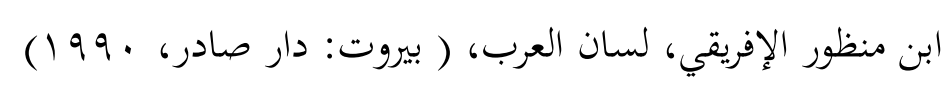

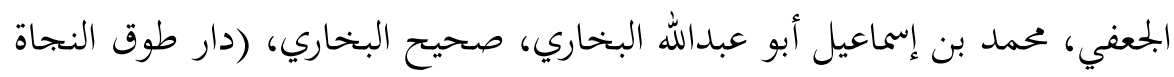

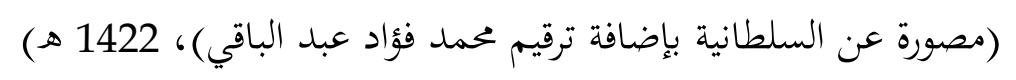

الجارم ،علي و أمين، مصطفى، دليل البلاغة الواضحة، (لبنان: المكتبة العلمية)

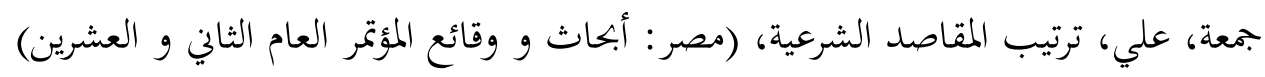

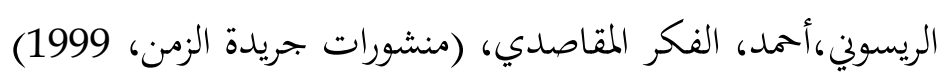

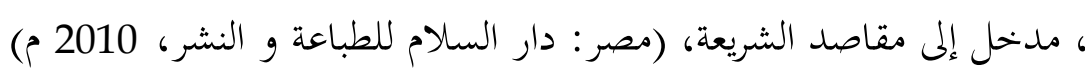


الزحيلي،مصطفى، القواعد الفقهية وتطبيقاتحا في المذاهب الأربعة، (دمشق: دار الفكر،

(2006 1.

$$
\text { الزحيلي، وهبة، أصول الفقه الإسلاي، (سورية: دار الفكر، 1986) }
$$

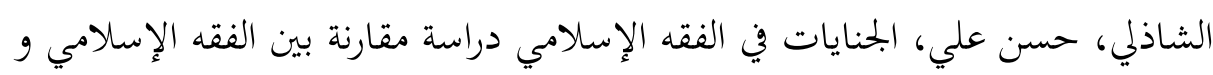

$$
\text { القانون، (القاهرة: دار الكتب الجامعي، 1978) }
$$

الشاطبي، إبراهيم بن موسى بن محمد اللخمي الغرناطي، الموافقات، (دار ابن عفان،

عودة، جاسر، مقاصد الشريعة دليل للمبتدئ، ( الولايات المتحدة الأمريكية: المعهد

العالمي للفكر الإسلامي، 2011)

\section{ب. المجلات}

ابن عمر، عمر بن صالح، ضوابط تفعيل مقاصد الشريعة، (قطر : جامعة قطر، 2009 م)

أديتيا، ديتو، و اخرون، أثر جائحة كوفيد- 19 نحو اقتصادية إندونيسيا، (سومطرا الغربية:

بحلة بينيفيتا للتنمية الاقتصادية، إدارة الأعمال و الحساب، 2020)، ج. 5، رو ـ 2. أمين، عبد الرعوف محمد، ضوابط العمل بمقاصد الشريعة في الممارسات الاجتهادية،

(إندونيسيا: بحلة لبحوث الحضارة الإسلامية في جنوب شرق اسيا، 2014) ج. 3، ر. 2.

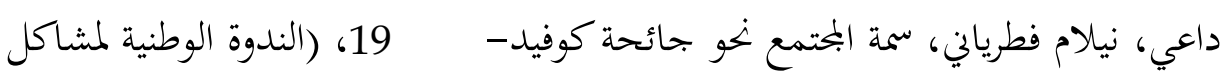

$$
\text { اجتماعية نحو كوفيد-19، } 20 \text { مايو 2020) }
$$

دوكيس، فينسينسو، استجابة الدول لمعالمة جائحة كوفيد -19، (سورابايا: جرنال العالمي

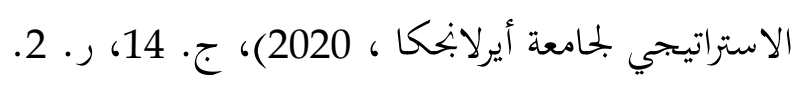

ريستياواتي، أفريستا، فعالية تنفيذ انتخاب رؤساء الدوائر 2020 عند الجحائحة في إندونيسيا،

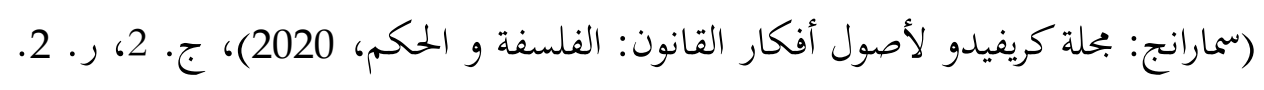

شين، بي، و اخرون، التحقيق في تفشي سارس-كوف- 2 بين ركاب الحافلات في شرق

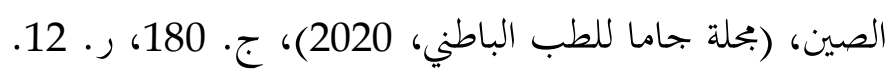

عرفان معتصم باللهمحمد، نظرية العيش في العادي الجديد نظرا من الفقه الإسلامي،

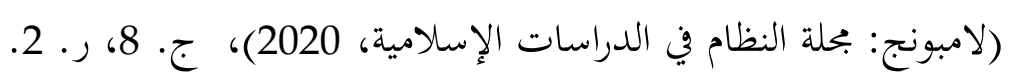


الفريق، الضوابط التوجيهية الحفاظية للأطباء عند أزمة كوفيد- 19، (جاكرتا: رابطة أطباء جمهورية إندونيسيا، 2020)، ص. 16.

مهتدي أنصار، أحمد، و عز المتقين، محمد، سياسة حكومة إندونيسيا في منع تفشي كوفيد-19 من نظرية مقاصد الشريعة، (بنجكولو: بحلة الاستنباط للأحكام الإسلامية، 2020)،

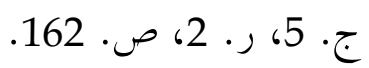

وريانداني، ديوي، اثار جائحة كوفيد -19 نحو تطور اقتصادية إندونيسيا 2020 و الحلول عنها، (جاكرتا: مركز بحث بحلس النواب للجمهورية إندونيسيا، 2020)، ج. 12، ر. 1، ص. 20.

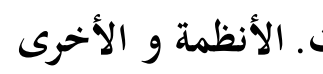

تقرير اقتصادية جمهورية إندونيسيا في الفصل الثالث 2020 للمكتب المركزي للإحصاء الرقم 85، 5 نوفمبر 2020.

28

$$
\text { سبتمبر 2020)، ص. 1. }
$$

قرار رئيس جمهورية إندونيسيا الرقم 9 سنة 2020 عن تغيير القرار الرقم 7 سنة 2020 عن الفريق الخاص لمكافحة كوفيد-19.

نظام الوزارة الصحية عن إرشادات معلومات تتعلق بتضييق النشاط الاجتماعي رقم 09

نظام الوزارة الصحية لجمهورية إندونيسيا عن معلومات البروتوكول الصحي للمجتمع من

$$
\text { أجل الوقاية و التدبير على تفشي كوفيد-19 رقم 2020/382/01.07 نظام حكومة جمهورية إندونيسيا الرقم } 21 \text { سنة 2020. }
$$

$$
\text { ث.ثوقع الإنترت }
$$

https://asiatimes.com/2020/09/china-celebrates-virus-success-aseurope-suffers $/$, accessed on 09/28/2020

https:/ / www.cnnindonesia.com/nasional/20200910162303-32545027 / paslon-pilkada-positif-covid-19-meningkat-jadi-60-orang, accessed on $09 / 28 / 2020$

https://covid19.go.id/peta-sebaran

who.int 
معالجة فيروس كورونا بإندونيسيا في ضوء مقاصد الشريعة

https://kumparan.com/kumparannews/viral-wakil-ketua-dprdtegal-gelar-hajatan-panggung-dangdut-di-tengah-corona-

1uFxo9GY3so/full, accessed on09/25/2020

https:/ / money.kompas.com/read/2020/09/11/070200226/kala-3-

menteri-ekonomi-jokowi-singgung-anies-soal-psbb-

jakarta?page=all\#page3, accessed on 09/24/220

https:/ / www.movehub.com/blog/best-and-worst-covidresponses/\#three, accessed on 09/24/2020

https:/ / republika.co.id/berita/qgaquq354/bawaslu-paslonlanggar-protokol-kesehatan-akan-kena-sanksi, accessed on 09/28/2020 


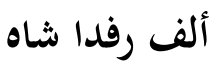

Halaman ini sengaja dikosongkan 